\title{
Prognostic Significance of Immunohistochemical Expression of p53 and Retinoblastoma Gene Protein (pRB) in Curatively Resected Gastric Cancer
}

\author{
Hong Suk Song, M.D., In Ho Kim, M.D. ${ }^{2}$, Soo Sang Sohn, M.D. ${ }^{2}$, \\ Kun Young Kwon, M.D. ${ }^{3}$ and Won Sik Lee, M.D. ${ }^{4}$ \\ Departments of Internal Medicine, General Surgery ${ }^{2}$ and Pathology $y^{3}$, Keimyung University School of Medicine, \\ Daegu, Korea: Department of Internal Medicine, Fatima Hospital', Daegu, Korea
}

\begin{abstract}
Background : The aim of this study was to determine the prognostic significance of the expression of $p 53$ and retinoblastoma $(\mathrm{Rb})$ gene products in cases of curatively resected gastric adenocarcinoma, by immunohistochemical analysis.

Methods : Between January 1996 and December 2001, 736 curatively resected gastric cancer patients underwent immunohistochemical staining for $p 53$ or Rb proteins (pRb), and we retrospectively analyzed the correlation of our results with the clinical outcomes of these cases.

Results : High levels of expression of $p 53$ (>25\% p53-positive cells) and $\mathrm{Rb}$ ( $>50 \%$ Rb-positive cells) proteins were detected in $40.1 \%$ and $43.7 \%$ of cases, respectively. Tubular type was found to frequently exhibit higher levels of $p 53$ expression (high expression in $44.2 \%$ ) than signet ring cell type (high expression in $26.0 \%)(p=0.042)$. The incidence of vascular invasion was lower in the high pRb expressors (43.2\%) than in the pRb low expressors (56.8\%), but this was not a statistically significant discrepancy $(p=0.063)$. Preoperative CEA levels were found to be low in high pRb expressors: initial CEA level in the high pRb expressors was $2.31 \pm 3.30 \mathrm{ng} / \mathrm{mL}$, and was $5.18 \pm 24.80 \mathrm{ng} / \mathrm{mL}$ in the low $\mathrm{pRb}$ expressors $(p=0.033)$. Tumor depth and node metastasis were both independent of the levels of expression of $p 53$ and $\mathrm{Rb}$ proteins. The seven-year overall survival rate and relapse-free survival rates of patients were $87.2 \%$ and $75.7 \%$, respectively. Multivariate Cox regression analysis indicated that tumor stage, tumor size, patient age and pRb expression were the significant prognostic factors with regard to overall survival, and tumor stage and age were both significant factors with regard to relapse-free survival.

Conclusion : Immunohistochemical staining of retinoblastoma gene products was an independent prognostic factor for the prediction of overall survival in curatively resected gastric cancer patients.
\end{abstract}

Key Words : Gastric cancer, Prognosis, p53, Rb gene, Immunohistochemistry

\section{INTRODUCTION}

Gastric cancer is one of the most common cancers, representing the second leading cause of cancer deaths in Korea. A population-based cancer registry was established on January 1 , 1997 to estimate the incidence of cancer in Daegu. The age-standardized incidence rates (ASR) of gastric cancer were 73.5 per 100,000 males and 28.9 per 100,000 females, as reported by the Daegu Cancer Registry in 2002. Recently, the proportion of gastric cancer cases among all malignancies is declining: annual reported cases of gastric cancer constituted $24.1 \%$ of all cancers in 1990 , and $20.8 \%$ of all cancers in 2000 ,

- Received : July 27, 2004

- Accepted : September 22, 2004

- Correspondence to : Hong Suk Song, M.D., Department of Hematooncology, Dongsan Medical Center, Keimyung University School of Medicine, 194 Dongsan-dong, Choong-Koo, Daegu, 700-712, Korea Tel : 82-53-250-7436, Fax : 82-53-250-7434 E-mail : shs7436@dsmc.or.kr 
as reported by the Korea Cancer Registry Program. This decline appears to be due principally to changes in diet and food preparation, as well as an increased incidence of early diagnosis of gastric cancer.

Greater insight has recently been gained into the biological properties of tumor cells. Tumor suppressor gene products are of specific interest, as they play important roles in cell cycle regulation. The $p 53$ tumor suppressor gene normally regulates cell proliferation, ${ }^{1,2)}$ and programmed cell death ${ }^{3,4)}$. Abnormalities of the $p 53$ tumor suppressor gene have been implicated in both tumorigenesis and tumor progression. The retinoblastoma gene is a prototype of the tumor suppressor gene which controls the cell cycle at the G1 phase ${ }^{5,6)}$, and the Rb gene product (pRb) functions as a signal transducer, connecting the cell cycle with the transcriptional machinery. The Rb gene product, pp110Rb, is a nuclear phosphoprotein which exhibits DNA binding properties $^{6}$, and it is cyclically phosphorylated and dephosphorylated during the cell cycle, playing a significant role in regulation ${ }^{5-7)}$. Loss of pRB function deprives the cell of an important mechanism for halting proliferation ${ }^{8)}$. The importance of $p 53$ expression has been extensively analyzed with regard to a plethora of human malignancies, including gastric cancer, by immunohistochemical methods, while the role of retinoblastoma gene protein expression has been studied, but certainly not to so significant a degree ${ }^{9)}$. The prognostic roles of the above gene expressions with regard to gastric cancer remain controversial. The purpose of this study was to determine the prognostic significance of $p 53$ and $\mathrm{Rb}$ protein expression in curatively resected gastric adenocarcinoma.

\section{MATERIALS AND METHODS}

\section{Patients and setting}

From January 1996 to December 2001, 2,104 pathologically confirmed gastric cancer patients were registered in our hospital. Of these, 1,158 were curatively resected patients. In 736 of these patients, immunohistochemical analyses of p53 or $\mathrm{Rb}$ proteins were performed. We reviewed the clinicopathological parameters of TNM stage, the World Health Organization classifications, histological grades, Lauren classifications, Ming classifications, vascular invasion rates, and nerve invasion rates in all 736 patients. Staging evaluation was done according to the 5th edition guidelines published by the American Joint Committee of Cancer.

Curative resection was defined as the removal of all gross tumors, and the demonstration of tumor-negativity by microscopic examination, in both proximal and distal surgical margins. Total gastrectomy was performed in 114 patients (15.5\%), subtotal gastrectomy in 622 patients (84.5\%), D1 and D1+a resection in 232 patients (31.5\%), and D2 and D2+a resection in 504 patients $(68.5 \%) .494(67.1 \%)$ of these patients were male, and $242(32.9 \%)$ were female. The mean age of the subjects was 57.1 years (range: $19-80$ years). Staging was as follows: IA in $338(45.9 \%)$ patients, IB in 104 patients (14.1\%), II in 115 patients (15.6\%), IIIA in 106 patients (14.4\%), and IIIB in 73 patients $(9.9 \%)$. The median follow-up duration was 37.8 months (range: 0.8 to 97.3 months) (Table 1).

Table 1. Clinical characteristics of curatively resected gastric cancer patients

\begin{tabular}{lll}
\hline \hline Number of patients & Male & 736 \\
Sex & Male & $494(67.1 \%)$ \\
& Female & $242(32.9 \%)$ \\
Age, years & Mean & 57.1 \\
& Range & $19-80$ \\
Operation method & Total gastrectomy & $114(15.5 \%)$ \\
& Subtotal gastrectomy & $622(84.5 \%)$ \\
& D1, D1 + a & $232(31.5 \%)$ \\
Stage & D2, D2 + a & $504(68.5 \%)$ \\
& T1/T2/T3/T4 & $378 / 138 / 217 / 3$ \\
& NO/N1/N2 & $467 / 173 / 96$ \\
& IA & $338(45.9 \%)$ \\
& IB & $104(14.1 \%)$ \\
& II & $115(15.6 \%)$ \\
& IIIA & $106(14.4 \%)$ \\
\end{tabular}


Immunohistochemical staining

Immunohistochemical staining was performed using the avidin-biotin-peroxidase complex with monoclonal antibodies against p53 (NCL-p53-D07, Novocastra Laboratories, Newcastle, United Kingdom), and Rb (14001A, Pharmingen, USA). Representative paraffin blocks containing tumors isolated from each case subject were sectioned into $5 \mu \mathrm{m}$ slices and affixed to slides, then dried for 1 hour at $60^{\circ} \mathrm{C}$. The sections were deparaffinized in xylene, and rehydrated with a descending series of alcohol concentrations. Endogenous peroxidase activity was blocked by $3 \%$ hydrogen peroxidase for 15 minutes, followed by washing with phosphate buffered saline (PBS), at a $\mathrm{pH}$ of 7.2. The sections were then subjected to a heat antigen retrieval process, by autoclaving with $1 \%$ zinc sulfate solution for 5 minutes. After 20 minutes of cooling at room temperature, the sections were incubated with 10\% normal horse serum (Vectastain Elite kit) for 30 minutes. After decanting away the excess serum, sections were incubated with primary antibody for 2 hours at $37^{\circ} \mathrm{C}$. In the p53 study, DO7 monoclonal antibody was used at a 1:100 dilution (Novocastra, Newcastle, UK), and in the Rb study, the monoclonal antibody NCL-Rb1 was used, at a 1:500 dilution (Pharmingen, USA). The sections were subsequently incubated with prediluted biotinylated anti-mouse immunoglobulin (Vectastain Elite kit) for 30 minutes at $37^{\circ} \mathrm{C}$. After washing with PBS, the sections were allowed to react with peroxidase-conjugated streptoavidin (Dako, USA) at a dilution of $1: 500$ for 30 minutes at $37^{\circ} \mathrm{C}$. After washing with PBS, peroxidase activity was evaluated with 3,3'-diaminobenzidine tetrahydrochloride (DAB), and the sections were counterstained with Mayer's hematoxylin.

All sections were examined by 2 pathologists, who were blind to the clinical outcomes and features of the patients. The sections were scored according to the percentage of positive cells using the following categories: $0=$ negative, $1=1 \sim 10 \%$, $2=11 \sim 25 \%$, 3=26 50\%, 4=51 75\% and 5=76 100\%. A breast cancer biopsy specimen showing intense uniform positivity for pRb was used as a positive control, as was a squamous cell lung cancer biopsy specimen exhibiting uniform positivity for p53.

In the statistical analysis of $p 53$ and $\mathrm{Rb}$ expression, the tmors were further categorized, into three and two groups respectively. Tumors expressing p53 protein in over $25 \%$ of cells with strong staining were designated as high p53 expressors, and tumors expressing p53 protein in $1 \sim 25 \%$ of cells or weak staining were designated as low p53 expressors. Tumors exhibiting no p53 expression were designated negative $p 53$ expressors. With regard to $\mathrm{pRb}$ expression, tumors expressing $\mathrm{pRb}$ in over $50 \%$ of cells with strong staining were designated high pRb expressors, and tumors expressing $\mathrm{pRb}$ in less than $50 \%$ of cells or weak staining were designated as low

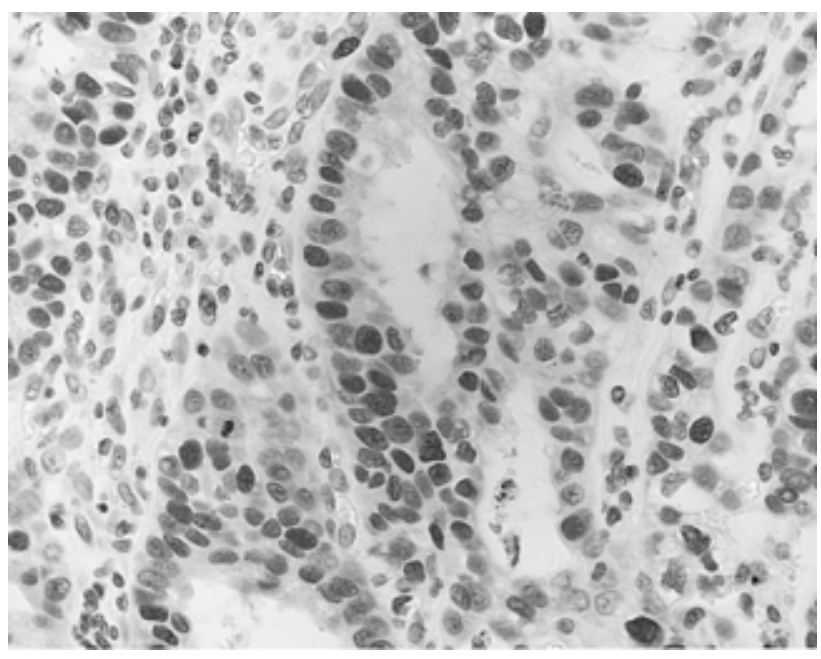

Figure 1. Immunohistochemical staining for $\mathrm{Rb}$ evidences high expression in the nuclei of tumor cells $(\times 400)$.

pRb expressors (Figure 1). These classifications were predicated on the observations of previous studies ${ }^{10}$.

\section{Statistics}

Statistical analysis was performed using $x^{-2}$ tests, in order to compare percentages in cross tabulations, and independent sample $t$-tests were used to compare the means. Survival curves were generated by the Kaplan-Meier method, and compared using the log-rank test. To determine the significant prognostic factors in terms of survival and relapse-free survival, multivariate analysis was performed with the Cox proportional hazards regression model. All significance levels listed refer to two-sided tests. $p$ values of $<0.05$ were considered to be significant.

Statistical analyses were performed using SPSS for Windows 11.0 (Chicago, II, USA).

\section{RESULTS}

Tumor samples with high, low and no $p 53$ protein expression were found in $287(40.1 \%), 120$ (16.8\%) and 309 (43.2\%) of the 716 samples. High and low pRb expressors were found in 317 $(43.7 \%)$ and $409(56.3 \%)$ of the 726 samples examined, respectively (Table 2 ).

\section{Correlation with clinicopathologic parameters}

According to the classifications provided by the World Health Organization, tubular-type adenocarcinoma (low and high p53 expressors in $17.9 \%$ and $44.2 \%$ ) was frequently more $p 53$ positive than signet ring cell type (low and high p53 expressors in $15.0 \%$ and $26.0 \%) \quad(p=0.042)$. The incidence of vascular 
Table 2. Immunohistochemical expression rates according to histologic characteristics of curatively resected gastric cancer patients

\begin{tabular}{|c|c|c|c|c|c|c|}
\hline & & \multicolumn{3}{|c|}{$p 53$} & \multicolumn{2}{|c|}{$\mathrm{Rb}$} \\
\hline & & Negative & low & high & low & high \\
\hline Total & & $309(43.2 \%)$ & $120(16.8 \%)$ & $287(40.1 \%)$ & $409(56.3 \%)$ & $317(43.7 \%)$ \\
\hline Vascular & positive & $98(41.2 \%)$ & $38(16.0 \%)$ & 102 (42.9\%) & $150(60.5 \%)$ & $98(39.5 \%)$ \\
\hline invasion & negative & $115(43.6 \%)$ & $40(15.2 \%)$ & 109 (41.3\%) & $141(52.2 \%)$ & $129(47.8 \%)$ \\
\hline $\mathrm{WHO}$ & tubular & $146(37.9 \%)$ & $69(17.9 \%)$ & $170(44.2 \%)$ & $222(55.8 \%)$ & $176(44.2 \%)$ \\
\hline classification & signet-ring & 59 (59.0\%) & $15(15.0 \%)$ & $26(26.0 \%)^{*}$ & $61(59.8 \%)$ & $41(40.2 \%)$ \\
\hline Histologic & well differentiated & $27(35.5 \%)$ & $15(19.7 \%)$ & $34(44.7 \%)$ & $47(58.8 \%)$ & $33(41.3 \%)$ \\
\hline \multirow[t]{2}{*}{ grade } & moderate differentiated & $105(40.1 \%)$ & $44(16.8 \%)$ & $113(43.1 \%)$ & $158(59.8 \%)$ & $106(40.2 \%)$ \\
\hline & poorly differentiated & $132(44.0 \%)$ & $52(17.3 \%)$ & $116(38.7 \%)$ & $162(52.9 \%)$ & $144(47.1 \%)$ \\
\hline Lauren & intestinal & $152(40.0 \%)$ & $63(16.6 \%)$ & $165(43.4 \%)$ & $215(55.7 \%)$ & $171(44.3 \%)$ \\
\hline classification & diffuse & $135(48.6 \%)$ & $39(14.0 \%)$ & $104(37.4 \%)$ & $154(55.0 \%)$ & $126(45.0 \%)$ \\
\hline Nerve & positive & $95(40.1 \%)$ & $33(13.9 \%)$ & $109(46.0 \%)$ & $131(54.4 \%)$ & $110(45.6 \%)$ \\
\hline invasion & negative & $144(43.0 \%)$ & $56(16.7 \%)$ & $135(40.3 \%)$ & $197(56.8 \%)$ & $150(43.2 \%)$ \\
\hline
\end{tabular}

" $p<0.05$ : WHO classification according to p53 expression

invasion was lower in the high pRb expressors (43.2\%) than in the low pRb expressors (56.8\%), but this was not a statistically significant difference $(p=0.063)$. Preoperative CEA levels were low in the high $\mathrm{pRb}$ expressors: the initial CEA level in the high $\mathrm{pRb}$ expressors was $2.31 \pm 3.30 \mathrm{ng} / \mathrm{mL}$, and $5.18 \pm 24.80 \mathrm{ng} / \mathrm{mL}$ in the low $\mathrm{pRb}$ expressors $(p=0.033)$.

No significant correlations were observed with regard to the overexpression of $p 53$ and $\mathrm{Rb}$ proteins, and Lauren classifications, Ming classifications, tumor size, depth of invasion (pT category), lymph node involvement ( $\mathrm{pN}$ category), or pathologic stages.

\section{Survival analysis}

The 7-year overall survival rate was $87.2 \%$ among the total patient population (Table 3) and the relapse-free survival rate (Table 4) was $75.7 \%$ among the total patient population. According to stage, the 7-year overall survival rate of stage IA was $97.5 \%$, stage IB $92.7 \%$, stage $\| 86.2 \%$, IIIA $66.5 \%$ and

Table 3. Overall survival rate of curatively resected gastric cancer patients

\begin{tabular}{|c|c|c|c|c|c|c|c|}
\hline & & 1 year & 3 year & 5 year & 7 year & Mean & (months) \\
\hline Total & & $96.1 \%$ & $89.6 \%$ & $88.0 \%$ & $87.2 \%$ & 87.8 & \\
\hline Stage & $\begin{array}{l}\text { IA } \\
I B \\
I I \\
I I A A \\
I I I B\end{array}$ & $\begin{array}{l}98.2 \% \\
96.1 \% \\
96.4 \% \\
94.0 \% \\
88.4 \%\end{array}$ & $\begin{array}{l}97.5 \% \\
92.7 \% \\
90.3 \% \\
76.5 \% \\
63.7 \%\end{array}$ & $\begin{array}{l}97.5 \% \\
92.7 \% \\
86.2 \% \\
73.9 \% \\
56.6 \%\end{array}$ & $\begin{array}{l}97.5 \% \\
92.7 \% \\
86.2 \% \\
66.5 \% \\
56.6 \%\end{array}$ & $\begin{array}{l}90.6 \\
91.2 \\
81.2 \\
67.9 \\
57.3\end{array}$ & $p=.000$ \\
\hline$p 53$ & $\begin{array}{l}\text { high } \\
\text { low } \\
\text { negative }\end{array}$ & $\begin{array}{l}95.0 \% \\
96.6 \% \\
96.7 \%\end{array}$ & $\begin{array}{l}90.0 \% \\
90.7 \% \\
88.7 \%\end{array}$ & $\begin{array}{l}90.0 \% \\
85.3 \% \\
87.7 \%\end{array}$ & $\begin{array}{l}90.0 \% \\
85.3 \% \\
86.2 \%\end{array}$ & $\begin{array}{l}79.5 \\
87.1 \\
83.5\end{array}$ & $p=.914$ \\
\hline $\mathrm{Rb}$ & $\begin{array}{l}\text { high } \\
\text { low }\end{array}$ & $\begin{array}{l}96.8 \% \\
95.2 \%\end{array}$ & $\begin{array}{l}92.7 \% \\
87.2 \%\end{array}$ & $\begin{array}{l}92.7 \% \\
84.8 \%\end{array}$ & $\begin{array}{l}92.7 \% \\
83.3 \%\end{array}$ & $\begin{array}{l}82.4 \\
81.5\end{array}$ & $p=.013$ \\
\hline
\end{tabular}

Table 4. Relapse free survival rate of curatively resected gastric cancer patients

\begin{tabular}{llllllll}
\hline \hline & & 1 year & 3 year & 5 year & 7 year & Mean & (months) \\
\hline Total & & $97.5 \%$ & $86.9 \%$ & $79.2 \%$ & $75.7 \%$ & 81.9 & \\
p53 & high & $98.1 \%$ & $88.2 \%$ & $78.1 \%$ & $78.1 \%$ & 74.5 & \\
& low & $98.1 \%$ & $91.1 \%$ & $82.2 \%$ & $72.6 \%$ & 82.0 & $p=.719$ \\
& negative & $96.6 \%$ & $84.3 \%$ & $78.9 \%$ & $75.3 \%$ & 78.2 & \\
$\mathrm{R}$ Rb & high & $98.7 \%$ & $87.9 \%$ & $78.1 \%$ & $72.9 \%$ & 74.7 & \\
& low & $96.5 \%$ & $86.0 \%$ & $79.4 \%$ & $78.1 \%$ & 79.0 & $p=.741$ \\
\hline
\end{tabular}


Table 5. Multivariate analysis of the prognostic factors for total survival and relapse free survival in curatively resected gastric cancer patients

\begin{tabular}{|c|c|c|c|c|c|c|}
\hline & Overall & survival & & Relapse & free & survival \\
\hline & $\mathrm{RR}$ & $95 \%$ & $\mathrm{Cl}$ & $\mathrm{RR}$ & $95 \%$ & $\mathrm{Cl}$ \\
\hline Age & 1.030 & 1.007 & 1.053 & 1.019 & 1.000 & 1.037 \\
\hline Stage I vs. II & 2.144 & 0.945 & 4.867 & 7.032 & 3.311 & 14.931 \\
\hline I vs. IIIA & 5.561 & 2.737 & 11.295 & 14.676 & 7.178 & 30.003 \\
\hline I vs. IIIB & 8.305 & 3.932 & 17.542 & 25.379 & 12.110 & 53.187 \\
\hline Tumor size & 1.107 & 1.001 & 1.224 & 1.044 & 0.958 & 1.139 \\
\hline $\mathrm{Rb}$ & 0.557 & 0.333 & 0.933 & 0.925 & 0.617 & 1.385 \\
\hline
\end{tabular}

stage IIIB 56.6\% ( $p=0.000)$.

There were no significant differences detected in terms of total survival $(p=0.914)$ and relapse-free survival rates $(p=0.719)$ between patients with no, low, and high p53 expression characteristics. The 7-year overall survival rate of high $\mathrm{pRb}$ expressors $(92.7 \%)$ was better than in the low pRb expressors $(83.3 \%)(p=0.013)$ but the 7 -year relapse-free survival rate was similar between the two.

According to multivariate Cox regression analysis, tumor stage, tumor size, patient age, and $\mathrm{pRb}$ expression rates (RR $0.557,95 \% \mathrm{Cl} 0.333-0.933)$ were the important prognostic factors in overall survival rates (Table 5).

\section{DISCUSSION}

Among the various malignancies, gastric cancer represents the second most common cause of cancer death throughout the world, and the prognosis for advanced gastric cancer remains quite poor. The expression of the $p 53$ and $\mathrm{Rb}$ genes can be easily detected in a variety of human malignancies, including gastric cancer, by immunohistochemical methods, but its prognostic roles in gastric cancer remain controversial. The p53 tumor suppressor gene, which is localized in the short arm of human chromosome 17 (17p13.1), plays an important role in the control of tumors, by regulating the expression of vascular endothelial growth factor (VEGF) ${ }^{111}$. The levels of wild-type $p 53$ protein are normally extremely low and, due to its short half-life, it is undetectable by standard immunohistochemical staining in normal cells and tissues. Conversely, the mutated p53 protein accumulates in the nucleus, either by binding with other oncogenic proteins, or by prolonging its half-life ${ }^{12}$. The nuclear accumulation of $p 53$ was consistent with p53 mutation rates, and exhibited the same subtype specificity ${ }^{13)}$. About $40 \%$ of our gastric cancer cases (287/716) evidenced high reactivity to $p 53$, which is consistent with previous studies, in which $p 53$ overexpression was found to be common in gastric cancers ${ }^{14-18)}$.

The $\mathrm{Rb}$ gene was the initial tumor suppressor gene discovered in childhood retinoblastomas ${ }^{19}$. The $\mathrm{Rb}$ gene normally codes for a nuclear phosphoprotein, but both copies of the gene are inactivated in retinoblastomas ${ }^{19)}$. It is now believed that the $\mathrm{Rb}$ protein $(\mathrm{pRb})$, the product of the $\mathrm{Rb}$ gene, functions as a signal transducer, connecting the cell cycle with the transcriptional machinery. The $\mathrm{Rb}$ gene can be inactivated by DNA mutations, deletions, undetectable or reduced mRNA expression, or undetectable or aberrant protein production. Loss of pRB function deprives the cell of an important mechanism for halting proliferation ${ }^{8)}$. pRb phosphorylation induces the inactivation of its growth inhibitory functions, via the release of transcription factor E2F, which is required for progression into the $S$ phase ${ }^{8,20)}$. Ogawa et al..$^{9)}$ reported finding overexpression of the $\mathrm{Rb}$ gene in $51.1 \%$ of gastric cancer cases, and in our study, $43.7 \%$ (317/726) of cases exhibited a high degree of reactivity to $\mathrm{Rb}$.

The majority of tumors exhibited $\mathrm{Rb}$ and $p 53$ located in the nucleus. This is consistent with previous studies ${ }^{21)}$ and appears to occur via the regulation of transcriptional factors.

Regarding the WHO histopathologic classifications, positive immunohistochemical staining of c-erbB-2 protein was significantly higher in the tubular type of gastric cancer than in the signet ring cell type ${ }^{22)}$. However, positive nuclear $p 53$ expression was found to be significantly higher in the tubular type of gastric cancer in our study; positive p53 expression was detected in $62.1 \%$ of tubular type gastric cancer cases, but only in $41.0 \%$ of the signet ring cell type $(p=0.042)$. This is similar to the results reported by Uchino et al. ${ }^{12)}$, in which nearly $40 \%$ of papillary adenocarcinomas were associated with the nuclear accumulation of the p53 protein. The incidence of c-erbB-2 expression was higher in intestinal-type carcinomas than in diffuse carcinomas ${ }^{16)}$, but in our study, we detected no differences between the Lauren classifications and p53 and Rb expression.

In the previous studies, p53 expression was associated with vascular invasion ${ }^{14,17,23)}$ and in our study, vascular invasion was less frequent in high $\mathrm{pRb}$ expressors than in low pRb expressors. However, this was not a statistically significant difference $(p=0.063)$. No significant correlations were detected with regard to age, sex, tumor size, depth of tumor invasion, lymph node metastasis, or the overexpression of $p 53$ and $\mathrm{Rb}$ proteins in our study of curatively resected gastric cancer 
patients.

In our study, the 7-year survival rate was $87.2 \%$ and the relapse-free survival rate was $75.7 \%$. The 7 -year survival rates, according to stage, were as follows: stage IA 97.5\%, IB 92.7\%, stage II 86.2\%, stage IIIA 66.5\% and stage IIIB 56.6\%.

According to multivariate Cox regression analyses, tumor stage, tumor size, age, and $\mathrm{Rb}$ expression were the relevant prognostic factors in terms of total survival, and tumor stage and age were the most important prognostic factors with respect to relapse-free survival. Currently, the most accurate prognostic indicator for gastric cancer is tumor stage ${ }^{24)}$. Age is also an important prognostic factor in gastric cancer; however, it was associated with increased treatment-related mortality in our study ${ }^{25}$. In our study, p53 overexpression was not found to be an independent prognostic marker. In previous studies, p53 expression was a useful marker in intestinal-type only ${ }^{26,27)}$. Our study also determined no significant differences to exist with regard to Lauren histological types.

We did, however, demonstrate a significant difference in survival curves between high- and the low- expressors of the $\mathrm{Rb}$ gene. The $\mathrm{Rb}$ gene was found to be an independent prognostic factor in the prediction of total survival. It has been determined that reduced $\mathrm{Rb}$ expression was associated with poor prognoses in stage | and || non-small cell lung carcinoma ${ }^{28)}$, and that $\mathrm{Rb}$-positive tumors were associated with significantly better survival rates inboth ovarian cancer $^{10)}$ and gastric cancer ${ }^{9}$.

In conclusion, immunohistochemical staining for the $\mathrm{Rb}$ protein proved to be a clinically useful prognostic indicator in cases of curatively resected gastric cancer. Conversely, high p53 expression is not an independent indicator for survival. Further prospective studies are warranted, in order to clarify the relationship between tumor suppressor proteins and gastric cancer prognoses, and cell cycle regulation associated with the action of these proteins.

\section{REFERENCES}

1) Mercer WE, Shields MT, Lin D, Appella E, Ullrich SJ. Growth suppression induced by wild-type p53 protein is accompanied by selective down-regulation of proliferating cell nuclear antigen expression. Proc Nat Acad Sci U S A 88:1958-1962, 1991

2) Fields $S$, Jang SK. Presence of a potent transcription activating sequence in he p53 protein. Science 249:1046-1049, 1990

3) Sachs L, Lotem J. Control of programmed cell death in normal and leukemic cells: new implications for therapy. Blood 82:15-21, 1993

4) Wyllie $\mathrm{AH}$. Apoptosis and the regulation of cell numbers in normal and neoplastic tissues: an overview. Cancer Metastasis Rev 11: 95-103, 1992

5) Wiman KG. The retinoblastoma gene: role in cell cycle control and cell differentiation. FASEB J 7:841-845, 1993

6) Bookstein R, Lee WH. Molecular genetics of the retinoblastoma suppressor gene. Crit Rev Oncog 2:211-227, 1991

7) Buchkovich K, Duffy LA, Harlow E. The retinoblastoma protein is phosphorylated during specific phases of the cell cycle. Cell 58: 1097-1105, 1989

8) Weinberg RA. The retinoblastoma protein and cell cycle control. Cell 81:323-330, 1995

9) Ogawa M, Maeda K, Chung YS, Onoda N, Kato Y, Nakata B, Sowa M. Correlation between expression of RB protein and prognosis of gastric cancer. Gan To Kagaku Ryoho 23(Suppl 2):148-150, 1996

10) Dong $Y$, Walsh MD, McGuckin MA, Cummings MC, Gabrielli BG, Wright GR, Hurst T, Khoo SK, Parsons PG. Reduced expression of retinoblastoma gene product (pRB) and high expression of p53 are associated with poor prognosis in ovarian cancer. Int $J$ Cancer 74:407-415, 1997

11) Maeda K, Kang SM, Onoda N, Ogawa M, Sawada $T$, Nakata $B$, Kato Y, Chung YS, Sowa M. Expression of p53 and vascular endothelial growth factor associated with tumor angiogenesis and prognosis in gastric cancer. Oncology 55:594-599, 1998

12) Finlay $C A$, Hinds PW, Tan $T H$, Eliyahu $D$, Oren $M$, Levine AJ. Activating mutations for transformation by 053 produce a gene product that forms an hsc70-p53 complex with an altered half-life. Mol Cell Biol 8:531-539, 1988

13) Uchino $S$, Noguchi M, Ochiai $A$, Saito $T$, Kobayashi M, Hirohashi $S$. p53 mutation in gastric cancer: a genetic model for carcinogenesisis common to gastric and colorectal cancer. Int J Cancer 54:759-764, 1993

14) Maehara $Y$, Tomoda M, Hasuda S, Kabashima A, Tokunaga E, Kakeji Y, Sugimachi K. Prognostic value of p53 protein expression for patients with gastric cancer: a multivariate analysis. Br J Cancer 79:1255-1261, 1999

15) Gomyo $Y$, Ikeda M, Osaki M, Tatebe S, Tsujitani S, Ikeguchi M, Kaibara N, Ito $H$. Expression of p21(waf1/cip 1/sdi1), but not p53 protein, is a factor in the survival of patients with advanced gastric carcinoma. Cancer 79:2067-2072, 1997

16) Shun CT, Wu MS, Lin JT, Chen SY, Wang HP, Lee WJ, Wang TH, Chuang SM. Relationship of p53 and c-erbB-2 expression to histological features: Helicobacter pylori infection and prognosis in gastric cancer. Hepatogastroenterology 44:604-609, 1997

17) Ichiyoshi $Y$, Oiwa H, Tomisaki S, Sakaguchi $Y$, Ohno S, Maehara $\mathrm{Y}$, Sugimachi K. Overexpression of p53 is associated with growth pattern and prognosis in advanced gastric cancer. Hepatogastroenterology 44:546-553, 1997

18) Lim BH, Soong R, Grieu F, Robbins PD, House AK, lacopetta BJ. p53 accumulation and mutation are prognostic indicators of poor survival in human gastric carcinoma. Int J Cancer 69:200-204, 1996

19) Friend $\mathrm{SH}$, Bernards R, Rogelj $\mathrm{S}$, Weinberg RA, Rapaport JM, Albert DM, Dryja TP. A human DNA segment with properties of the gene that predisposes to retinoblastoma and osteosarcoma. Nature 323:643-646, 1986

20) Kastan MB, Onyekwere O, Sidransky D, Vogelstein B, Craig RW. Participation of $p 53$ protein in the cellular response to DNA damage. Cancer Res 51:6304-6311, 1991

21) Pedley J, Ablett EM, Pettit A, Meyer J, Donn IS, Sturm RA, Parsons PG. Inhibition of retinoblastoma protein translation by UVB 
in human melanocytic cells and reduced cell cycle arrest following repeated irradiation. Oncogene 13:1335-1342, 1996

22) Yokota J, Yamamoto $T$, Miyajima N, Toyoshima K, Nomura $N$, Sakamoto H, Yoshida T, Terada M, Sugimura T. Genetic alterations of the c-erb2 oncogene occur frequently in tubular adenocarcinoma of the stomach and are often accompanied by amplification of the $v$-erbA homologue. Oncogene 2:283-287, 1988

23) Gabbert HE, Muller W, Schneiders A, Meier S, Hommel G. The relationship of p53 expression to the prognosis of 418 patients with gastric carcinoma. Cancer 76:720-726, 1995

24) Santoro E, Carboni M, Catarci M, Carlini M, Carboni F, Zupi G, Vecchione A, D'Agnano I, Giannarelli D, Santoro R, Farofalo A. DNA ploidy, proliferative index and EGF-R status in 130 cases of resected gastric cancer: a multivariate analysis. Hepatogastroenterology
44:826-837, 1997

25) Song H, Do Y, Kim I, Sohn S, Lee W. Prognostic significance of age in curatively resected gastric cancer. Proc Am Soc Clin Oncol 23:344, 2004

26) Guadagni S, Reed PI, Johnson BJ, de Bernardinis G, Catarci M, Valenti M, di Orio F, Carboni M. Early gastric cancer: follow-up after gastrectomy in 159 patients. Br J Surg 80:325-328, 1993

27) Hurlimann J, Saraga EP. Expression of p53 protein in gastric carcinomas: association with histologic type and prognosis. Am J Surg Pathol 18:1247-1253, 1994

28) Xu HJ, Hu SX, Cagle PT, Moore GE, Benedict WF. Absence of retinoblastoma protein expression in primary non-small cell lung carcinoma. Cancer Res 51:2735-2739, 1991 